\title{
HEALTH CARE WORKERS IN WAKE OF COVID-19 ERA
}

\author{
KHALID WAHEED ${ }^{1}$, MUNAZA JAVED ${ }^{2}$ \\ ${ }^{I}$ Department of Pulmonology \& Sleep Medicine, Postgraduate Medical Institute/Ameer ud Din Medical College/ \\ Lahore General Hospital, Lahore
}

How to cite this article: Waheed K, Javed M. Health care workers in wake of covid-19 era. Pak Postgrad Med J 2020;31(2): 43-44

This is an Open Access article distributed under the terms of the Creative Commons Attribution License (http://creativecommons.org/licenses/by/3.0), which permits unrestricted use, distribution, and reproduction in any medium, provided the original work is properly cited.

By the end of December 2019 clusters of mysterious pneumonias were reported in Wuhan, capital city of Hubei province, China which was later diagnosed to be caused by a novel corona virus. This virus belongs to a large family of Corona viruses which caused diseases like SARS and MERS in the past. It is is now named as SARS-CoV-2 virus causing a disease named as COVID-19., 2 Within months this highly contagious abysmal virus spread like wild fire across multiple continents. Finally COVID-19 was declared a pandemic by World health organization (WHO) by mid of March, $2020 .^{3}$

Till date SARS-CoV-2 virus has infected more than 18 million people worldwide with a variable case fatality rate around $2.3 \%$. The statistics of Pakistan are not different than the rest of the world, here by the end of July there are around 270000 total cases with 5899 deaths with a fatality rate of $2.1 \%{ }^{4}$ The spread of COVID-19 infection is through respiratory droplet and contact routes. ${ }^{5,}$ However recent reports are discussing fecao-oral transmission and airborne transmission as other possible routes of transmission. Initially it was thought that only the symptomatic patients were able to transmit the disease but multiple recent studies have reported that asymptomatic patients can also spread the disease. $^{6,7}$

Global outbreak of COVID-19 has put the health care systems of both the developed and developing countries under tremendous pressure. Health care systems are currently working at their maximum capacity during this pandemic for the last six months. Health care workers form the backbone of any Health care system, and are working day in and day out in providing efficient health care to their patients. Health care workers including doctors, nurses, paramedics and the administration of hospitals are in the forefront battling this deadly virus.
To limit the spread of COVID 19 infection strict lock downs were implemented worldwide during which millions of people stayed at home to limit the spread of this deadly pathogen. On the contrary our frontline HCWs during this time of an international emergency attended to their patients' needs in the hospitals and clinics not only putting themselves at risk of COVID 19 infection but also their families. In Italy $20 \%$ of HCWs were reported to be infected with COVID-19 which makes up $10 \%$ of the total disease burden, out of which many have succumbed to this disease. China's National Health Commission has reported till the end of March 2020 around 3300 health-care workers to be affected by the virus. ${ }^{8}$

This pandemic has taken a great toll on physical and mental health of HCWs due to long endless duty hours, staff shortages, deficient PPE, losing patients and Colleagues daily, all these were affecting their attention, understanding, decision making, judgment and general well-being. ${ }^{9,} 10$ Health care systems are in a state of emergency worldwide but unlike the wards, hospitals and equipments, HCWs cannot perform their duties to $100 \%$ for longer periods of time nor they can be manufactured on emergency bases. It is imperative for the Governments to cater to needs of HCWs and ensure their safety.

Some salient factors responsible for this high infection rate in HCWs are, firstly this virus was a new pathogen whose dynamics were initially not clearly understood and use of proper personal protection was not stressed upon in the beginning. ${ }^{11}$ Secondly most of the initial cases did not disclose their travel history to their health care providers which resulted in infection of not only the HCWs but also to their family members. ${ }^{12}$

It is now clear that during this pandemic implementation of infection prevention and control (IPC) is of pivotal importance regarding personal protection of healthcare workers. Shortage of personal 
protective equipment (PPE) has led to increased infection rate in HCWs. Some of the HCWs were already managing COVID 19 infected patients while waiting for their supplies of PPE. These shortages of PPE led the HCWs to develop quick fixes or reuse of disposable gear repeatedly, both these factors did not offer the same level of protection as professional quality gear could provide. Similarly using N95 respirator without a proper prior fit test in aerosol generating areas lead to high infection rate of HCWs. ${ }^{13,14}$

HCWs are certainly Hero's of today but we do need them for tomorrow. They are the most valuable resource of any country which needs to be protected in order to provide continuous health care services. Certain changes are recommended to ensure safety of HCWs. First of all services, commitment and sacrifices of HCWs should be acknowledged not only at government level but also by general public which would improve their morale and ultimately will have a positive effect on patient care. All HCWs should be provided with proper area specific PPE including surgical masks, N95 respirator, goggles, face shields, gowns, and suits. A proper fit test should be performed prior to assigning them to aerosol generating areas (ICUs, HDUs, bronchoscopy suites and diagnostic labs), and size specific N95 respirators should be made available to them. Staff motivation can also be increased by offering health risk allowances and compensations to the HCWs in working with COVID-19 infected patients. In wake of this pandemic all nonessential and elective services in hospitals should be discontinued to limit the spread of infection and reduce the undue burden on HCWs. In this regard telemedicine would be an excellent option to cater to the need of general public while limiting the spread.

In coming days a falling trend of COVID 19 infection is being anticipated in Pakistan due to implementation of strict lockdowns and proper implementation of SOPs all over the country but we should remain vigilant as a second wave of COVID 19 is being witnessed in many countries of which Australia is on the top of the list. In short to prevent the second wave of infection in Pakistan we should all adhere to social distancing, proper hand washing and face mask use. On the same time to limit the risk of infection in HCWs, awareness of personal protection should be increased, sufficient PPE provision should be assured and proper preparedness and response should be instituted so that we are better prepared for combating a second wave if required.

\section{REFERENCES}

1. Kannan S, Shaik SAP, Sheeza A, Hemalatha K, COVID19 (Novel Coronavirus 2019) Recent Trends, Eur Rev Med Pharmacol Sci2020 Feb;24(4):2006-2011)

2. WHO Director-General's remarks at the media briefing on 2019-nCoV on 11 February 2020 [Internet]. Who.int. 2020 [cited 15 June 2020]. Available from: https://www.who.int/dg/speeches/detail/whodirectorgeneral-s-remarks-at-the-media-briefing-on-2019-ncovon-11-february-2020

3. WHO Director-General's opening remarks at the media briefing on COVID-19 - 11 March 2020.World Health Organisation 2020. Available: https://www.who.int/ $\mathrm{dg} /$ speeches/detail/who-director-general-s-openingremarks-at-the-media-briefing-on-covid-19 11-march-20

4. Coronavirus cases and deaths- world meter (internet). World meter.info.2020(cited $2^{\text {nd }}$ Aug.2020). available from; www.worldmeter.info/coronavirus/\#counter.

5. Centers for Disease Control and Prevention (CDC). COVID-19 transmission. 2020. www.cdc.gov/coron aviru s/2019-ncov/ prepare/transmission.html

6. WHO Novel coronavirus (2019-nCoV) situation report_2. Jan 22, 2020. www.who.int/docs/defaultsource/coronaviruse/situation-reports/20200122-sitrep-22019-ncov.pdf

7. Rothe C, Schunk M, Sothmann P. Transmission of 2019$\mathrm{nCoV}$ Infection from an Asymptomatic Contact in Germany. N Engl J Med. 2020 doi:10.1056/NEJMc 2001468.2020 Jun; 10(1): 010357.

8. COVID-19: protecting health-care workers. Lancet. 2020;395:401.

9. Kang L, Hu S, Chen M. The mental health of medical workers in Wuhan, China dealing with the 2019 novel coronavirus. Lancet Psychiatry. 2020; 7 :e 14.

10. Waise K. Doctors fear bringing Coronavirus home: 'I Am Sort of a Pariah in My Family.' New York Times. 2020. Available: https://www.nytimes.com/2020/03/16/ us/coronavirus-doctors-nurses.html.

11. Wang J, Liu F, Tan JBX, Harbarth S, Pittet D, Zingg W. Implementation of infection prevention and control in acute care hospitals in Mainland China e a systematic review. Antimicrob Resist Infect Control 2019;8:32.

12. Nagesh $\mathrm{S}$, Chakraborty $\mathrm{S}$. Saving the frontline health workforce amidst the COVID-19 crisis: Challenges and recommendations J Glob Health. 2020 Jun; 10(1): 010345. Published online 2020 Apr 24. doi: 10.7189/jogh-10-010345

13. Chang D, Xu H, Rebaza A, Sharma L, Dela Cruz CS. Protecting health-care workers from subclinical coronavirus infection. Lancet Respir Med 2020 Feb 13

14. World Health Organization. Shortage of personal protective equipment endangering health workers worldwide. 2020. https://www.who.int/news-room/detai 1/03-03-2020-short age-of-personalprotective equipment-endangering-health-workers-worldwide. 